\title{
Learning from the first release project of captive-bred mandrills Mandrillus sphinx in Gabon
}

\author{
Patricia Peignot*, Marie J.E. Charpentier*, Nicolas Bout, Olivier Bourry, Ulrich Massima, Olivier Dosimont, \\ Roxanne Terramorsi and E. Jean Wickings
}

\begin{abstract}
We report the results of the first release project of 36 captive-bred mandrills into the Lékédi Park, Gabon. A mortality rate of $33 \%$ was recorded in the first year post-release, with dependent infants the most affected age class, as a result of environmental stress and malnutrition. A programme of provisioning ensured that individuals remained in a good physical condition. During the second year the death rate decreased to $4 \%$, and 6-month survival rate of infants was $100 \%$. Over time the mandrills extended their spatial use of the park, although their exploration remained limited. Our results demonstrate that provisioning and the lack of knowledge of ecological
\end{abstract}

characteristics of the new, complex seasonal habitat were the likely causes of this situation. After 2 years, reproduction and survival appear stable. While habitat preservation and in situ species protection are the best conservation options, release projects may constitute a viable short-term solution for particular species. In this context, this first release of captive-bred mandrills could play a role in the future conservation of this Vulnerable species.

Keywords Gabon, Lékédi Park, Mandrillus sphinx, post-release monitoring, provisioning, rehabilitation, spatial use.

\section{Introduction}

The role of translocation and reintroduction programmes in the conservation of endangered species has been widely discussed, with particular focus on ethical implications, ecological, disease and genetic impacts on local natural populations, and the longterm monitoring and survival of introduced populations (Wolf et al., 1998; Fischer \& Lindenmayer, 2000; Linklater, 2003; Tuberville et al., 2005). The future of several species has been heavily dependent on the reintroduction of captive-bred individuals (Snyder \&

Patricia Peignot $\uparrow$ (Corresponding author), Olivier Bourry, Roxanne Terramorsi and E. Jean Wickings Centre International de Recherches de Franceville (CIRMF), BP 769, Franceville, Gabon. E-mail peignotp@yahoo.fr

Marie J.E. Charpentierł CEFE-CNRS UMR 5175, 1919 Route de Mende, 34293 Montpellier Cedex 5, France.

Nicolas Boutł Université Blaise-Pascal, Clermont-Ferrand II, France.

Ulrich Massima and Olivier Dosimont Société du Développement du Parc de la Lékédi, COMILOG, Bakoumba, Gabon.

${ }^{*}$ Contributed equally to this work.

${ }^{\dagger}$ Current address: 431, rue de Pioulouse, 40600 Biscarrosse, France.

${ }^{\ddagger}$ Also at: Centre International de Recherches de Franceville (CIRMF), BP 769, Franceville, Gabon.

Received 16 June 2006. Revision requested 26 September 2006. Accepted 21 November 2006. First published online 14 January 2008.
Snyder, 1989; Stanley-Price, 1989; Moore \& Smith, 1991; Csermely \& Corona, 1994).

Primates are one of the most threatened orders of mammals (IUCN, 1996) and many species, threatened in their natural habitat, have been the focus of translocation and reintroduction projects to augment their chances of survival (Horwich et al., 1993; Struhsaker \& Siex, 1998; Kleiman \& Rylands, 2002). To date the long-term success of such programmes has been difficult to assess (Yeager, 1997; Kessel \& Brent, 2001; Beck et al., 2002). The case of primates is problematic because each species presents different and complex socioecological challenges based on social organization and feeding and habitat preferences (Goodall, 1968; Yeager, 1997).

Primates bred in captivity in habitat countries could have advantages over ex situ programmes for the reintroduction of threatened species (Snyder et al., 1996) because such programmes present more economic alternatives. The Centre International de Recherches Médicales de Franceville (CIRMF) in Gabon established a semi-captive ranging breeding colony of Mandrillus sphinx for non-invasive biomedical research in the early 1980s. The initial group of 15 founders (bushmeat orphans aged 1-8 years) had reached $>100$ individuals by 2002 , resulting in overcrowding and habitat degradation. The instigation of contraceptive measures will limit future breeding but cannot alleviate current conditions. Hence, alternative measures to reduce numbers were sought. 
The feasibility study of a release project took into consideration several factors: (1) The mandrill is categorized as Vulnerable on the IUCN Red List (IUCN, 2007) but little information is available on range, population sizes, density, and threats from hunting and habitat loss. (2) The species' habitat varies from degraded to closed canopy forest to forest-savannah mosaic, and diet is eclectic (Hoshino, 1986; Lahm, 1986; Rogers et al., 1996), indicating that the mandrill can adapt to a variety of forest habitats and exploit a wide range of food items. The semi-captive ranging mandrills have opportunities to develop the foraging (Norris, 1988), locomotive and predator avoidance skills (against snakes and raptors but not carnivores) consistent with forest living. (3) Social organization in wild mandrills can vary from one-male harems to multi-male, multifemale groups showing fission-fusion (Sabater Pi, 1972; Jouventin, 1975; Hoshino et al., 1984; Lahm, 1985; Harrison, 1988; Ancrenaz, 1994; Rogers et al., 1996; Abernethy et al., 2002), indicating the social adaptability of this species. The captive individuals selected for release had developed the social skills requisite for group cohesion. (4) There is a neighbouring ranch, the Lékédi Park, with space to accommodate and protect a group of mandrills, and a vegetation survey of a 12 ha area (Abernethy, 2000) demonstrated that $50 \%$ of plant species known to be consumed by wild mandrills are present (Lahm, 1986; Rogers et al., 1996). Given the similarities in vegetation between this 12 ha area and the surrounding area chosen for the release, we assumed that the variety and abundance of feeding resources would be sufficient. Frequent observation of groups of wild mandrills in another area of the Park indicated that our assumption was correct.

Although IUCN does not recommend release projects to dispose of surplus animals (IUCN, 2002) the setting of the release site and the apparent adaptability of the mandrill were sufficient justifications for the first release of captive mandrills to a wild environment. This experimental release project had two aims: to reduce the level of overpopulation in the CIRMF breeding colony and to contribute to an understanding of the requirements for primate rehabilitation and reintroduction projects, and in particular for any future mandrill translocations. Assessments of the release are carried out at annual intervals and here we report the first two such assessments.

\section{Methods}

\section{Animals}

Thirty-six mandrills (16 males and 20 females) from the CIRMF breeding group were chosen for translocation
(Table 1). They had all been born within the colony and had grown up in a 6 ha forested enclosure. Three female matrilines were chosen as the core group (Table 1) as well as one adult and two subadult males. These males were chosen so as to reduce intra-sexual aggression in the semi-captive colony and to observe the dispersal pattern of subadult males in the wild. Six individuals (four males, two females) were fitted with radio collars (Telonics, Mesa, USA) to track them after release, assuming that the females would remain within the group and that the males would sooner or later adopt more peripheral positions (Abernethy et al., 2002). All mandrills were treated for gastrointestinal parasites immediately prior to transfer, as recommended (IUCN, 2002). All mandrills were genotyped for the cytochrome b locus to ensure they were compatible with the geographic haplotype found in the south of Gabon (Telfer et al., 2003).

\section{Release site}

The ranch of the Société du Développement du Parc de la Lékédi is situated at Bakoumba c. $100 \mathrm{~km}$ from CIRMF, Franceville (Fig. 1). It includes three fenced areas of 650 ha (Module 1, M1), 1,750 ha (Module 2, M2) and 11,600 ha (Module 3, M3; Fig. 1). The landscape is principally closed canopy forest with some areas of forest-savannah mosaic and is rich in the fauna typical of southern and central Gabon, except for the forest elephant Loxodonta africana. Leopards constitute the most serious risk for reintroduced mandrills because they were absent from the enclosure at CIRMF. M2 was chosen for the release because of its suitable area compared to M1 and M3, which were, respectively, too small for the group and too large for ease of tracking. There was no evidence of groups of wild mandrills in M2, but solitary adult males had been observed. M2 has approximately $80 \%$ forest cover, including closed canopy forest, riverine galleries and immature forest (Fig. 1).

\section{Transfer}

Mandrills were transferred under anaesthesia from CIRMF to Bakoumba in two groups on 28 August and 19 September 2002, accompanied by veterinary staff. To acclimatize the mandrills to their new habitat they were initially placed in a small holding enclosure of 0.5 ha within M2 (Fig. 1), where they were provisioned twice daily with the same food as at CIRMF. The full release into M2 was on 1 October 2002, by opening the gate in the fence of the holding area. 
Table 1 Details of mandrills selected for the rehabilitation project, indicating their age at release and matrilineal origins.

\begin{tabular}{|c|c|c|c|c|c|c|}
\hline Individual & Date of birth & Age at release (yrs) & Sex & Status $^{1}$ & Mother's identity & Membership \\
\hline $12 \mathrm{~A} 1^{2}$ & $03-02-87$ & 15.59 & Male & Adult & $12 \mathrm{~A}$ & Group \\
\hline 2D3 & 07-01-94 & 8.65 & Male & Subadult & 2D & Solitary (during the 1st yr) \\
\hline $12 \mathrm{~A} 6^{2}$ & $12-03-93$ & 8.75 & Male & Subadult & $12 \mathrm{~A}$ & Solitary (during the 1st yr) \\
\hline $2 C^{2}$ & $01-02-86$ & 16.59 & Female & Adult & 2 & Group \\
\hline $2 \mathrm{C} 4$ & $02-01-93$ & 9.47 & Female & Adult & $2 \mathrm{C}$ & Group \\
\hline $2 C 4 A^{2}$ & $23-02-97$ & 5.52 & Male & Adolescent & $2 \mathrm{C} 4$ & Solitary (during the 3rd yr) \\
\hline $2 \mathrm{C} 4 \mathrm{~B}$ & 08-02-99 & 3.56 & Female & Adult & $2 \mathrm{C} 4$ & Group \\
\hline $2 \mathrm{C} 6$ & $03-12-96$ & 5.75 & Female & Adult & $2 \mathrm{C}$ & Group \\
\hline $2 \mathrm{C} 6 \mathrm{~A}$ & $30-01-02$ & 0.59 & Female & Yearling & $2 \mathrm{C} 6$ & Group \\
\hline $2 \mathrm{C} 7$ & $05-02-98$ & 4.57 & Female & Adult & $2 \mathrm{C}$ & Group \\
\hline $2 \mathrm{C} 7 \mathrm{~A}$ & 31-01-02 & 0.58 & Female & Yearling & $2 \mathrm{C} 7$ & Group \\
\hline $2 \mathrm{C} 8$ & $17-03-99$ & 3.46 & Male & Juvenile & $2 \mathrm{C}$ & Group \\
\hline $2 \mathrm{C} 9$ & $16-11-00$ & 1.79 & Male & Juvenile & $2 \mathrm{C}$ & Group \\
\hline $2 \mathrm{C} 10$ & $05-02-02$ & 0.57 & Male & Yearling & $2 \mathrm{C}$ & Group \\
\hline $10 \mathrm{~K}$ & $13-01-97$ & 5.64 & Female & Adult & 10 & Group \\
\hline $10 \mathrm{~K} 1$ & 14-01-02 & 0.63 & Male & Yearling & $10 \mathrm{~K}$ & Group \\
\hline 10E2 & $12-12-96$ & 5.72 & Female & Adult & $10 \mathrm{E}$ & Group \\
\hline $10 \mathrm{E} 2 \mathrm{~A}$ & 20-02-01 & 1.53 & Female & Juvenile & 10E2 & Group \\
\hline $10 \mathrm{~F} 1^{2}$ & $18-11-96$ & 5.79 & Male & Adolescent & $10 \mathrm{~F}$ & Solitary (during the 2nd yr) \\
\hline $10 \mathrm{~F} 2$ & $12-03-98$ & 4.48 & Female & Adult & $10 \mathrm{~F}$ & Group \\
\hline $10 \mathrm{~F} 3$ & 08-04-99 & 3.40 & Male & Juvenile & $10 \mathrm{~F}$ & Group \\
\hline $12 \mathrm{D}$ & $29-09-87$ & 15.60 & Female & Adult & 12 & Group \\
\hline 12D7 & $17-11-97$ & 4.79 & Female & Adult & $12 \mathrm{D}$ & Group \\
\hline 12D7A & 03-01-02 & 0.59 & Male & Yearling & $12 \mathrm{D} 7$ & Group \\
\hline 12D8 & 02-03-99 & 3.50 & Male & Juvenile & $12 \mathrm{D}$ & Group \\
\hline 12D9 & $20-10-00$ & 1.87 & Male & Juvenile & $12 \mathrm{D}$ & Group \\
\hline 12D10 & $22-03-02$ & 0.45 & Female & Yearling & $12 \mathrm{D}$ & Group \\
\hline 12D3A & $12-02-98$ & 4.55 & Female & Adult & 12D3 & Group \\
\hline 12D3A1 & 08-02-02 & 0.56 & Male & Yearling & $12 \mathrm{D} 3 \mathrm{~A}$ & Group \\
\hline $12 \mathrm{C} 3$ & 02-03-93 & 9.51 & Female & Adult & $12 \mathrm{C}$ & Group \\
\hline $12 \mathrm{C} 3 \mathrm{C}$ & 29-01-01 & 1.59 & Female & Juvenile & $12 \mathrm{C} 3$ & Group \\
\hline $12 \mathrm{C} 3 \mathrm{D}$ & 05-04-02 & 0.41 & Female & Yearling & $12 \mathrm{C} 3$ & Group \\
\hline $12 \mathrm{~A} 9^{2}$ & $30-11-96$ & 5.76 & Female & Adult & $12 \mathrm{~A}$ & Group \\
\hline $12 \mathrm{~A} 9 \mathrm{~A}$ & $21-02-02$ & 0.61 & Male & Yearling & $12 \mathrm{~A} 9$ & Group \\
\hline $12 \mathrm{~A} 10$ & $03-02-98$ & 4.58 & Female & Adult & $12 \mathrm{~A}$ & Group \\
\hline $12 \mathrm{~A} 10 \mathrm{~A}$ & 24-01-02 & 0.60 & Male & Yearling & $12 \mathrm{~A} 10$ & Group \\
\hline
\end{tabular}

${ }^{1}$ At the beginning of the project (1 October 2002)

${ }^{2}$ Radio-collared

\section{Post-release monitoring}

Monitoring was by radio-tracking only, to avoid influencing group movements and foraging, with radiocollars located by triangulation. Spatial use was determined using daily fixes of all six collars. Day journey lengths (DJL) were calculated twice weekly using six fixes between 07.30 and 17.00 for each collar. During the first year (1 October 2002-1 October 2003), 1,400 positions were recorded, 810 for the group and 590 for the solitary subadult male (see below). DJL were measured until March 2004 during the second year (205 positions). After this period spatial use was monitored each time the group was contacted. We stopped triangulations for the solitary male in the second year because of the topography of the area used and also because he appeared to have adapted well to his new habitat during the first year. He was able to sustain himself on wild food items and, after several months without provisioning, he was still in good physical conditions (see below).

\section{Provisioning}

Visual contact with the group was re-established after 8 weeks of radio-tracking. Eight of the 10 ventral infants had disappeared and most of the animals were thin. The group was therefore provisioned daily with monkey chow for 1 month, followed by a progressive decrease to zero over 2.5 months. However, a month after cessation of provisioning, animals were again observed to be losing weight and a twice-weekly schedule of feeding was instigated. From the moment provisioning started, 


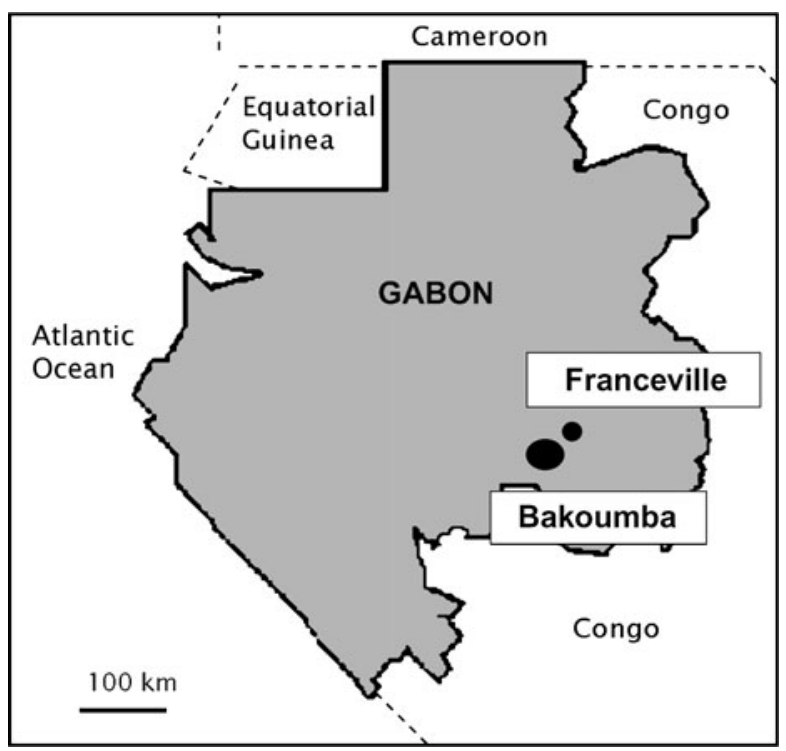

Fig. 1 Gabon, indicating the location of Lékédi Park (Fig. 2) at Bakoumba.

regular observations were made and visual health checked by CIRMF veterinarians. The frequency and quantity of provisioning took account of physiological requirements (pregnant females) and ecological conditions (seasonal fruit availability) but did not provide the animals' total calorific requirements, encouraging them to continue natural foraging. We did not use any fixed feeding location to avoid undue influence on ranging behaviour; food was provided where animals were located via telemetry. A botanical survey was carried out in the area used by the group to ascertain whether sufficient food resources were available. Mandrills were observed as they foraged and food items recorded when possible. A monthly phenology survey of a 120 ha area was set up to monitor fruiting patterns (Peignot, 2003).

\section{Statistical analyses}

The geographical information system ArcView v. 3.2 was used to plot coordinates of radio-locations, DJL and space used. Survival analysis was performed to study the effect of sex on death rate using SAS v. 9 (SAS, Cary, USA). Differences in distances travelled during periods with and without provisioning, with and without an adult male in the group, and distance travelled by the solitary adult male were compared using Wilcoxon tests. The effect of provisioning frequency on group DJL was also tested using a $Z$ correlation test. We did not study the effect of seasonality on DJL because this was itself highly correlated with provisioning frequency, which was, in turn, related to fruit availability.

\section{Results}

The first year post-release

Thirty-three per cent (12/36) of individuals released died, with dependent infants being the age class most affected (8/10 died); sex had no effect on survival ( $\mathrm{n}=36$, $\chi^{2}{ }_{1}=0.89, \mathrm{P}=0.35$ ). Only the emaciated body of an adult male was found and could be autopsied. Malnutrition and a high intestinal parasite load of Oesophagostomum sp. (family: Strongylidae) were the cause of death. We cannot rule out predation by leopard in the other cases as no other carcasses were found.

One subadult male (12A6) separated from the group immediately after the release. The second subadult (2D3) also left the group the following day. Social cohesion was maintained between females, infants and the group adult male (12A1). Male 2D3 returned to the group 3 months after the death of the group adult male. One adolescent male (10F1) became peripheral to the group 9 months after release and disappeared 2 months later. Six weeks after disappearance his radio collar was found, but no skeleton. There was no conclusive evidence for the death of this individual. Females were seen with sexual swellings 2 months after the release and the fertility rate was $42 \%(5 / 12$ females conceived). Two of five infants born survived $>6$ months.

As in the wild, the mandrills were observed feeding in the canopy as well as foraging extensively on the ground, searching through leaf litter and digging to find insects, tubers and roots. The botanical survey of 120 ha of the forest zone (Peignot, 2003) occupied by the group identified 56 plant species, 22 of which were consumed by the mandrills (Table 2). These 22 items formed only $9.2 \%$ of the known mandrill dietary repertory. However, 12 new species previously unrecognized as mandrill foods were observed being consumed (Table 2; Peignot, 2003). A previous botanical survey on a 12 ha area of M2 (Abernethy, 2000) identified 61 plant species, 33 of which were known as mandrill foods. Of these 33 species, 14 were not observed in our inventory.

The solitary male occupied a range of $2.4 \mathrm{~km}^{2}$ in the eastern part of M2 (Fig. 2) and showed a median DJL of $1.3 \pm \mathrm{SD} 0.9 \mathrm{~km}$. Five months after the release he left M2 for M3 (apparently by jumping over the fence) where he occupied an area of $1.3 \mathrm{~km}^{2}$. The group used a western area of $4 \mathrm{~km}^{2}$ (23\% of M2; Fig. 2) and had a median DJL of $1.2 \pm \mathrm{SD} 1.0 \mathrm{~km}$. The occupation of this limited area appeared inappropriate for their requirements because of food items being dispersed. DJL in the absence of provisioning were significantly longer than during provisioning (median $2.0 \pm$ SD $1.5 \mathrm{~km}$ and $1.0 \pm \mathrm{SD} 0.5 \mathrm{~km}$, respectively; Wilcoxon test, $z=-2.981, \mathrm{P}<0.01)$ and 
Table 2 The second botanical inventory (Peignot, 2003), indicating the species that released mandrills were observed to consume (and the parts eaten), and the species known to be eaten by wild mandrills.

\begin{tabular}{|c|c|c|c|c|}
\hline Family & Species name & Life-form & $\begin{array}{l}\text { Eaten }{ }^{1} \text { by released mandrills } \\
\text { and parts consumed }\end{array}$ & Evidence for consumption by wild mandrills \\
\hline \multirow[t]{2}{*}{ Anacardiaceae } & Pseudospondias microcarpa & Tree & & Rogers et al., 1996 \\
\hline & Trichoscypha acuminata & Tree & & Lahm, 1986 \\
\hline \multirow[t]{3}{*}{ Annonaceae } & Xylopia aethiopica & Tree & Fruit & Hoshino, 1986; Rogers et al., 1996 \\
\hline & Xylopia staudii & Tree & & Lahm, 1986 \\
\hline & Uvaria scabrida & Tree & & \\
\hline Apocynaceae & Landolphia sp. & Liane & Fruit & Hoshino, 1986; Rogers et al., 1996 \\
\hline \multirow[t]{2}{*}{ Arecaceae } & Laccosperma laeve & Raphia & Fruit & \\
\hline & Raphia humilis & Raphia & Fruit & \\
\hline \multirow[t]{4}{*}{ Burceraceae } & Aucoumea klaineana & Tree & & \\
\hline & Canarium schweinfurhthii & Tree & Fruit & \\
\hline & Dacryodes normandii & Tree & & Lahm, $1986^{2}$ \\
\hline & Santiria trimera & Tree & & Hoshino, 1986 \\
\hline \multirow[t]{2}{*}{ Caesalpiniaceae } & Hylodendron gabunense & Tree & & \\
\hline & Neochevaliededron stephanii & Tree & & \\
\hline \multirow[t]{3}{*}{ Chrysobalanaceae } & Marantes glabra & Tree & Fruit & \\
\hline & Marantes gabonensis & Tree & Fruit & \\
\hline & Parinari excelsa & Tree & Fruit & \\
\hline \multirow[t]{8}{*}{ Euphorbiaceae } & Bridelia ferruginea & Shrub & & \\
\hline & Croton mubango & Tree & & \\
\hline & Discoglypremna caloneura & Tree & & Lahm, 1986 \\
\hline & Macaranga sp. & Tree & & \\
\hline & Maprounea sp. & Tree & & \\
\hline & Ricinodendron heudelotti & Tree & & \\
\hline & Plagiostyles africana & Tree & & \\
\hline & Uapaca guineensis & Tree & & Rogers et al., 1996 \\
\hline Gramineae & Unknown species & Grass & Grass blade & Hoshino, 1986; Lahm, 1986; Rogers et al., 1996 \\
\hline Hypericaceae & Harungana madagascariensis & Shrub & & \\
\hline Irvingiaceae & Klainedoxa trilessi & Tree & & Lahm, 1986; Rogers et al., $1996^{2}$ \\
\hline Lecythidacaea & Petersianthus macrocarpus & Tree & & \\
\hline \multirow[t]{2}{*}{ Meliaceae } & Carapa procera & Tree & & \\
\hline & Entandophragma candollei & Tree & & \\
\hline \multirow[t]{5}{*}{ Mimosaceae } & Newtonia leucocarpa & Tree & Leaves, twigs & \\
\hline & Pentachletra eetveltana & Tree & Seed & Lahm, 1986; Rogers et al., $1996^{2}$ \\
\hline & Pentachletra macrophylla & Tree & & Lahm, 1986; Rogers et al., 1996 \\
\hline & Piptadeniastrum africanum & Tree & & \\
\hline & Unknown species & Tree & Leaves, twigs & \\
\hline \multirow[t]{3}{*}{ Moraceae } & Ficus sur & Shrub & & Lahm, 1986 \\
\hline & Musanga cecropioides & Tree & Fruit & Lahm, 1986 \\
\hline & Treculia africana & Tree & Fruit & \\
\hline \multirow[t]{2}{*}{ Myristicaceae } & Coelocaryon preussi & Tree & & \\
\hline & Pycnanthus angolensis & Tree & & Lahm, 1986; Rogers et al., 1996 \\
\hline Olacaceae & Strombosiopsis tetandra & Tree & & Hoshino, 1986 \\
\hline Palmae & Elaeis guineensis & Tree & Fruit & Rogers et al., 1996 \\
\hline Rhizophoraceae & Anopyxis sp. & Tree & Fruit & \\
\hline \multirow[t]{5}{*}{ Rubiaceae } & Crossopterys sp. & Shrub & & \\
\hline & Pausinystalia johimbe & Tree & & \\
\hline & Pauridiantha efarata & Shrub & & \\
\hline & Psychotria venosa & Shrub & Leaves, twigs & Rogers et al., 1996 \\
\hline & Psychotria vogeliana & Shrub & & Rogers et al., 1996 \\
\hline Rutaceae & Pagara tesmanii & Tree & & \\
\hline Sapindaceae & Eriocoelum macrocarpum & Tree & Fruit & \\
\hline Smilacaceae & Smilax kraussiana & Tree & Leaves, twigs & \\
\hline Verbenaceae & Vitex doniana & Tree & & Rogers et al., 1996 \\
\hline \multirow{3}{*}{ Zingiberaceae } & Aframomum leptolpesis & Herb & Fruit & Hoshino, 1986²; Lahm, 1986; Rogers et al., 1996 \\
\hline & Aframomum longipetiolatum & Herb & Fruit & Rogers et al., 1996 \\
\hline & Aframomum sp. & Herb & Fruit & Hoshino, 1986; Lahm, 1986; Rogers et al., 1996 \\
\hline
\end{tabular}

${ }^{1}$ Direct observations

${ }^{2}$ Only same genus 

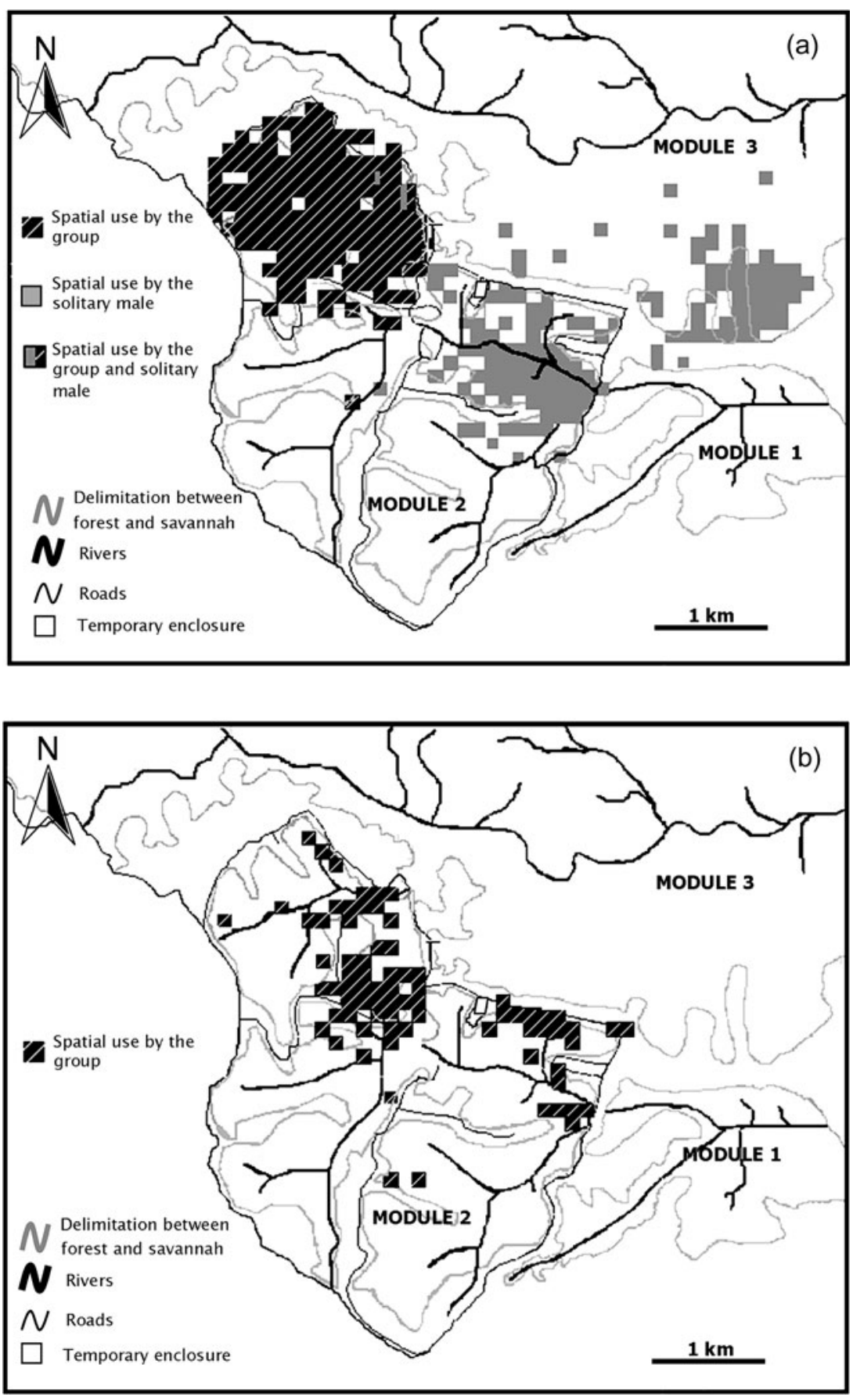

Fig. 2 Spatial use by (a) the group and the solitary male during the first postrelease year, and (b) by the group during the second post-release year. were inversely correlated with the frequency of provisioning ( $Z$ correlation coefficient $=-0.438, z=-2.97$, $\mathrm{P}<0.01)$. The presence of an adult male in the group did not influence DJL (with a male: $1.8 \pm \mathrm{SD}$ $1.7 \mathrm{~km}$; without a male: $2.6 \pm \mathrm{SD} 0.3 \mathrm{~km} ; z=-1,75$, $\mathrm{P}=0.79)$.

Solitary males clearly became self-sufficient. When male 12A6 left M2 for M3 he was no longer provisioned. Several months later, a transient observation indicated that he was in good physical condition. Male 2D3 was also in good condition and showed secondary sexual features characteristic of a healthy adult male on returning to the group after a 3-month absence. During this first post-release year the main problem for individuals in the group was to become self-sufficient, probably because of a lack of experience of the wild food resources available and restricted spatial use and exploration of their new habitat. 


\section{The second year}

Mortality rate decreased from 33\% in the first year to $4 \%$ in the second year. The overall fertility rate remained at $42 \%$ (five of 12 adult females conceived) but all five infants born in the second year survived at least 6 months. The area occupied by the group changed during the second year post-release, with a move to the east. The area used was approximately $3.5 \mathrm{~km}^{2}$ (Fig. 2) with a median DJL of $1.0 \pm$ SD $0.4 \mathrm{~km}$. No malnutrition was observed irrespective of season, with continual but minimal (twice per week) provisioning.

\section{Discussion}

This project was the first attempt to release a group of captive mandrills into a private wild park. Whereas habitat preservation and in situ species protection are the best conservation options, release projects are a viable solution in the short-term for some species. In this context, this study provided a unique opportunity to collect information about release processes in primates.

The presence of wild solitary individuals in the release area was considered an advantage because the opportunity to associate with and learn from them could improve survival of released individuals (Snyder et al., 1996). The M2 area also supports groups of frugivorous gorillas Gorilla gorilla gorilla, chimpanzees Pan troglodytes troglodytes and arboreal Cercopithecus species, supporting the pre-release assumption that the area contains a diversity of suitable food for primates. Moreover, the initial vegetation inventory (Abernethy, 2000) indicated sufficient diversity of resources for released mandrills, and we placed considerable importance on the eclectic diet of mandrills and on the past history of the released individuals.

The acquisition of self-sufficiency by the breeding group was problematic compared to the solitary males. However, the group showed progress during the second year post-release when they appeared to improve their foraging range and efficiency, although still minimally provisioned, even during the dry season when fruits were uncommon and females pregnant. Despite this limitation, all individuals remained in good physical condition during the second year. Successful rehabilitations of primates, and also of other mammals, have been those where individuals had previous experience of wild habitat over long periods (Aveling \& Mitchell, 1980; Hannah \& McGrew, 1991; Shepherdson, 1994). Forest-dwelling primates occupy a complex seasonal habitat (Tutin \& Fernandez, 1993a), of which knowledge is acquired over many years and generations. The acquisition of a mental map is critical for survival but this cannot be acquired rapidly (Boesch \& Boesch, 1984;
Sigg, 1986; Garber, 1989). Any translocated group will therefore be at a considerable disadvantage. Our vegetation inventory (Peignot, 2003) showed that feeding resources were more dispersed than expected. Such a patchy distribution of asynchronous resources, many of which have not been encountered before, cannot be learned in a short period of time. Furthermore, resource access could also be compromised by the presence of other frugivorous species because considerable dietary overlap occurs between mandrills and the gorillas, chimpanzees and arboreal Cercopithecus spp. present in M2 (Williamson et al., 1990; Tutin \& Fernandez, 1993b; Tutin et al., 1997). Although feeding competition can be minimized by differential spatial and time budgets (Lahm, 1986), it may present an additional handicap for released mandrills unused to such encounters. On one occasion we observed a contact with a wild gorilla that changed the ranging behaviour of the mandrills.

The decision not to influence group movements by close tracking caused us to delay making contact with the group for the first 8 weeks post-release. Moreover, the mandrills fled from the holding enclosure without returning, leading to a self-imposed choice of a hard release (i.e. without supplementary food) rather than a soft-release. The mandrills initially covered considerable distances each day and, when finally contacted, had lost body weight and condition even though the release occurred during the season of maximum fruit availability. Once initiated, long-term regular provisioning became essential because physical condition and well-being diminished rapidly, in particular in group males, at each attempt to withdraw supplementary feeding. The fragility of males living in a group can be explained by their higher energetic needs compared to females. The mandrill is highly sexually dimorphic; males weigh three times more than females and have a longer growth and developmental period (Setchell et al., 2001), and therefore have greater calorific requirements compared to females. Taking up a solitary existence may improve foraging efficiency in small patches, as well as reducing intra-sexual competition. Although the provisioning did not provide $100 \%$ of calorific needs for group members it appeared to render them less acquisitive for spatial exploration, as suggested also by Yeager (1997).

Infant survival increased to $100 \%$ in the second year, although fertility did not change. The survival of this generation, born in their new habitat, is important for the future of the group even if it is not sufficient to make up for the loss of dependent infants during the first year. The death rate decreased to $4 \%$ in the second year and this was one juvenile who suffered from malnutrition during the first year of release. Strum (2005) 
considered that survival rates play a more important role in the success of rehabilitation than birth rates as long as the released animals are able to reproduce. It is arguable that the loss of dependent infants could have been foreseen, this being the most vulnerable group. However, given that the release coincided with a period of major fruit availability there was no possibility of avoiding releasing either females with 6-month old offspring or pregnant females, given the breeding pattern of the CIRMF colony (Setchell et al., 2002). One solution would have been to prevent pregnancy by placing candidate release females under reversible contraception prior to the rehabilitation project.

Throughout the post-release monitoring social cohesion was observed, in particular between females and infants. Individuals remained in close contact with each other even after the death of the adult male (12A1) and until the reappearance of the now adult male (2D3). This social cohesion resembles that described in wild mandrill groups where females constitute the core of the group and males are only present during the reproductive season (Abernethy et al., 2002). Large adolescent and adult males may withdraw from the social group when females are not breeding to reduce intrasexual competition and to optimize foraging at times when their calorific requirements are high. The immediate disappearance of the two subadult males and the later peripheralization of the adolescent collared male (10F1) may reflect the dispersing behaviour of wild mandrills.

During the third year, in October 2004, a solitary wild male displaced the dominant group male (2D3) during the breeding season. Both 2D3 and the adolescent male (2C4A) disappeared from the group. The integration of this new male into the group introduced new genes by immediately impregnating females (five infants were then born), and influenced the ranging behaviour of the group. The mandrills foraged across the same zones as previously but extended their range to M1. Provisioning continued until September 2005 when the radio collars malfunctioned and contact was lost. When finally relocated in August 2006, in M1, the group numbered 22 individuals, including 12 of the mandrills originally released, all in good physical condition.

In the light of the experience gained during the 2 years of this study the following points should be considered in any future translocation or reintroduction of mandrills. (1) Avoid overestimation of the benefits of any prerelease social and ecological experience; our postrelease monitoring showed that, even when individuals had an almost ideal background, ecological adaptation was the most significant problem for the released mandrills. (2) Avoid a hard release whatever the background of the released individuals. (3) Avoid the release of females with dependent infants or during pregnancy by using reversible contraception.

Given the complexity of primate release projects and their role, in the short-term, for conservation, this project offered the opportunity to learn from the first release of captive mandrills to the wild. The recommendations arising from this project will be valuable for future translocation or reintroduction projects for mandrills and for the drill Mandrillus leucophaeus, the mandrill's Critically Endangered sister taxon. Both species have limited ranges within the rainforests of western central Africa, where deforestation and hunting for the bushmeat trade occur (Bowen-Jones \& Pendry, 1999; Chapman et al., 2006) and probably have a major impact on primate population sizes and viability. Information concerning viability of these primate species in a changing environment (i.e. from a buffered environment in captivity to a harsher environment in the wild) is therefore required, and this project constitutes an important step toward such studies.

\section{Acknowledgements}

We thank CIRMF for financial support for this study. CIRMF is funded by the Gabonese government, Total Gabon, and the French Ministry of Cooperation. MC was financed by the French Ministry of Foreign Affairs. We thank Société du Développement du Parc de la Lékédi, COMILOG, for permission to conduct this study in the Lékédi Park, and for providing technical support. We are grateful to K. Abernethy for advice about setting up the project, to E. Dimoto and J-T. Dikangadissi for help with the botanical inventory, and to B. Goossens and J. Setchell for advice on the manuscript. Helpful comments of two anonymous referees improved the manuscript.

\section{References}

Abernethy, K.A. (2000) Etude de la vegetation du future parc à gorilles, Sodépal, parc de la Lékédi, Bakoumba. Unpublished Report. CIRMF, Franceville, Gabon.

Abernethy, K.A., White, L.J.T. \& Wickings, E.J. (2002) Hordes of mandrills (Mandrillus sphinx): extreme group size and seasonal male presence. Journal of Zoology, 258, 131-137.

Ancrenaz, M., Tutin, C.E.G. \& Fernandez, M. (1994) Observations of Wild Mandrill Groups (Mandrillus sphinx) in Central Gabon. Abstract. XVth Congress of the International Primatological Society, Bali, Indonesia.

Aveling, R. \& Mitchell, A. (1980) Is rehabilitating orang-utans worth while? Oryx, 16, 263-271.

Beck, B.B., Rapaport, L.G. \& Wilson, A.C. (2002) Reintroduction of captive born animals. In Creative Conservation: Interactive Management of Wild and Captive Animals (eds P.J.S. Olney, G.M. Mace \& A.T.C. Feistner), pp. 265-286. Chapman and Hall, London, UK. 
Boesch, C. \& Boesch, H. (1984) Mental map in wild chimpanzees: an analysis of hammer transports for nut cracking. Primates, 25, 160-170.

Bowen-Jones, E. \& Pendry, S. (1999) The threat to primates and other mammals from the bushmeat trade in Africa, and how this threat could be diminished. Oryx, 33, 233-246.

Chapman, C.A., Lawes, M.J. \& Eeley, H.A.C. (2006) What hope for African primate diversity? African Journal of Ecology, 44, 116-133.

Csermely, D. \& Corona, C.V. (1994) Behavior and activity of rehabilitated buzzards (Buteo buteo) released in northern Italy. Journal of Raptor Research, 28, 100-107.

Fischer, J. \& Lindenmayer, D.B. (2000) An assessment of the published results of animal relocations. Biological Conservation, 96, 1-11.

Garber, P.A. (1989) Role of spatial memory in primate foraging patterns: Saguinus mystax and Saguinus fuscicollis. American Journal of Primatology, 19, 203-216.

Goodall, J. (1968) The behaviour of free living chimpanzees of the Gombe Stream Reserve. Animal Behaviour, 1, 161-311.

Hannah, A.C. \& McGrew, W.C. (1991) Rehabilitation of captive chimpanzees. In Primate Responses to Environmental Change (ed. H.O. Box), pp. 167-186. Chapman and Hall, London, UK.

Harrison, M.J.S. (1988) The mandrill in Gabon's rainforest: ecology, distribution and status. Oryx, 22, 218-228.

Horwich, R.H., Koontz, F., Saqui, E., Saqui, H. \& Glander, K. (1993) A re-introduction programme for the conservation of the black howler monkey in Belize. Endangered Species, 10, $1-6$.

Hoshino, J. (1986) Feeding ecology of mandrills (Mandrillus sphinx) in Campo Animal Reserve, Cameroon. Primates, 26 248-273.

Hoshino, J., Mori, A., Kudo, H. \& Kawai, M. (1984) Preliminary report on the grouping of mandrills (Mandrillus sphinx) in Cameroon. Primates, 25, 297-307.

IUCN (1996) African Primates. Status Survey and Conservation Action Plan. IUCN, Gland, Switzerland.

IUCN (2002) Guidelines for Non-human Primate Reintroductions. IUCN/SSC Reintroduction Specialist Group. IUCN, Gland, Switzerland.

IUCN (2007) 2007 IUCN Red List of Threatened Species. IUCN, Gland, Switzerland [http://www.iucnredlist.org, accessed 26 September 2007].

Jouventin, P. (1975) Observations sur la socio-écologie du mandrill. Terre et la Vie-Revue d'Ecologie Appliquée, 29, 439-532.

Kessel, A. \& Brent, L. (2001) The rehabilitation of captive baboons. Journal of Medical Primatology, 30, 71-80.

Kleiman, D. \& Rylands, A. (2002) Lion Tamarins: Biology and Conservation. Smithsonian Institution Press, Washington, DC, USA.

Lahm, S.A. (1985) Mandrill ecology and the status of Gabon's rainforest. Primate Conservation, 6, 32-33.

Lahm, S.A. (1986) Diet and habitat preference of Mandrillus sphinx in Gabon: implications of foraging strategy. American Journal of Primatology, 11, 9-26.

Linklater, W.L. (2003) A novel application of the Trivers-Willard model to the problems of genetic rescue. Conservation Biology, 17, 906-909.

Moore, D.E. \& Smith, R. (1991) The red wolf as a model for carnivore reintroduction. In Beyond Captive Breeding: Reintroduction of Endangered Mammals to the Wild (ed. J.H.W. Gipps), pp. 263-278. Clarendon Press, Oxford, UK.
Norris, J. (1988) Diet and feeding behavior of semi-free ranging mandrills in an enclosed gabonais forest. Primates, 29, 449-463.

Peignot, P. (2003) Etude de la vegetation dans les blocs forestiers principalement exploités par les mandrills du CIRMF transférés au parc de la Lékédi, Bakoumba, Gabon. Unpublished Report. CIRMF, Franceville, Gabon.

Rogers, M.E., Abernethy, K.A., Fontaine, B., Wickings, E.J., White, L.J.T. \& Tutin, C.E.G. (1996) Ten days in the life of a mandrill horde in the Lopé reserve, Gabon. American Journal of Primatology, 40, 297-313.

Sabater Pi, J. (1972) Contribution to the ecology of Mandrillus sphinx Linneaus, 1758 of Rio Muni (Republic of Equatorial Guinea). Folia Primatologica, 17, 304-319.

Setchell, J., Lee, P.C., Wickings, E.J. \& Dixon, A.F. (2001) The ontogeny of sexual dimorphism in mandrills (Mandrillus sphinx). American Journal of Physical Anthropology, 115, 349-360.

Setchell, J.M., Lee, P.C., Wickings, E.J. \& Dixon, A.F. (2002) Reproductive parameters and maternal investment in mandrills (Mandrillus sphinx). International Journal of Primatology, 23, 51-68.

Shepherdson, D. (1994) The role of environmental enrichment in the captive breeding and reintroduction of endangered species. In Creative Conservation: Interactive Management of Wild and Captive Animals (eds P.J.S. Olney, G.M. Mace \& A.T.C. Feistner), pp. 167-177. Chapman and Hall, London, UK.

Sigg, H. (1986) Ranging patterns in hamadryas baboons: evidence for a mental map. In Primate Ontogeny, Cognition and Social Behaviour (eds J. Else \& P. Lee), pp. 87-91. Cambridge University Press, Cambridge, UK.

Snyder, N.F.R., Derrickson, S.R., Beissinger, S.R., Wiley, J.W., Smith, T.B. Toone, W.D. \& Miller, B. (1996) Limitations of captive breeding in endangered species recovery. Conservation Biology, 10, 338-348.

Snyder, N.F.R. \& Snyder, H.A. (1989) Biology and conservation of the California condor. Current Ornithology, 6, 175-263.

Stanley-Price, M.R. (1989) Animal Re-Introductions: The Arabian Oryx in Oman. Cambridge University Press, Cambridge, UK.

Struhsaker, T.T. \& Siex, K.S. (1998) Translocation and introduction of the Zanzibar red colobus monkey: success and failure with an endangered island endemic. Oryx, 32, 277-284.

Strum, S.C. (2005) Measuring success in primate translocation: a baboon case study. American Journal of Primatology, 65, 117-140.

Telfer, P., Souquière, S., Clifford, S.L., Abernethy, K.A., Brudford, M.W., Disotell, T.R., Sterner, K.N., Roques, P., Marx, P.A. \& Wickings, E.J. (2003) Molecular evidence for deep phylogenetic divergence in Mandrillus sphinx. Molecular Ecology, 12, 2019-2024.

Tuberville, T.D., Clark, E.E., Bulhmann, K.A. \& Gibbon, J.W. (2005) Translocation as a conservation tool: site fidelity and movement of repatriated gopher tortoises (Gopherus polyphenmus). Animal Conservation, 8, 349-358.

Tutin, C.E.G. \& Fernandez, M. (1993a) Relationships between minimum temperature and fruit production in some tropical forest trees in Gabon. Journal of Tropical Ecology, 9, 241-248.

Tutin, C.E.G. \& Fernandez, M. (1993b) Composition of the diet of chimpanzees and comparisons with that of sympatric 
lowland gorillas in the Lopé reserve, Gabon. American Journal of Primatology, 30, 195-211.

Tutin, C.E.G., Ham, R.M., White, L.J.T. \& Harrison, M. (1997) The primate community of the Lopé reserve, Gabon: diets, responses to fruit scarcity, and effects on biomass. American Journal of Primatology, 42, 1-24.

Williamson, E.A., Tutin, C.E.G., Rogers, E. \& Fernandez, M. (1990) Composition of the diet of lowland gorillas at Lopé in Gabon. American Journal of Primatology, 21, 265-277.

Wolf, C.M., Garland, T. \& Griffith, B. (1998) Predictors of avian and mammalian translocation success: reanalysis with phylogenetically independent contrasts. Biological Conservation, 86, 243-255.

Yeager, C.P. (1997) Orang-utan rehabilitation in Tanjung Putting National Park, Indonesia. Conservation Biology, 11, 802-805.

\section{Biographical sketches}

Patricia Peignot is a primatologist interested in socioecology and cognitive processes in primates. Marie Charpentier is an evolutionary ecologist interested in mating systems, kin relationships and social structure in primates. Nicolas Bout and Roxanne Terramorsi are students of behavioural ecology involved in the release project. Olivier Bourry is a veterinarian working at CIRMF and was responsible for the mandrills' transfer. Olivier Dosimont is the manager of the Lékédi Park, where Ulrich Massima works as an ecotourism guide, and was also involved in the release project. Jean Wickings specializes in central African biodiversity and biogeography. 